\title{
A Heuristic Evaluation of Achik.biz Mobile Shopping App
}

\author{
Azham Hussain, Emmanuel O.C Mkpojiogu, Khairi Suleiman
}

\begin{abstract}
The purpose of this study is to present the report of the evaluation of a mobile print shop and design shopping application (Achik.biz). Following a dearth of studies on the usability of mobile print shop and design shopping application, $a$ study was conducted to evaluate the Achik.biz application. Heuristic methodology was used in the evaluation. The evaluation was conducted by 3 usability experts. The study reveals quite a number of usability issues related to the application.
\end{abstract}

\section{INTRODUCTION}

Following the revolution of internet usage, users' behavior has changed the way they purchase goods and services. Because of the busy nature of people nowadays, they are unable to shop in fixed stores; hence they are left with the option of shopping online, especially on their mobile devices. The rapid growth in the development of mobile phones has resulted to their habitual and daily resulting to the satisfaction of users' needs. Business card and others print shop products can now be booked and purchased by mobile phones users from online stores. The attachment of users to mobile phones depicts how easy these devices and the applications in them are to use (e.g. In the purchase of paperless tickets). The report on the global ecommerce from [1] posits that more than a half of global online purchasing accounted as follows, 58\% for fashion products, an average of $55 \%$ represents travel products or services, while book, music and stationery represent $50 \%$, meanwhile $43 \%$ accounts for it and mobile, while event for tickets represents $41 \%$ from the total respondents elicited globally. Mobile application provides ease in online purchasing that attracts customers, improves loyalty, profitability, and return on investment. The growth of the current mobile phone technology has opened and widened the opportunity for airlines, travel and tourism companies to make maximal benefits. Nielsen mobile wallet syndicated report in 2016 [2] maintains that canada smartphone owners form the vast majority $(76 \%)$ of users using their mobile phones in purchase-related activities. It was also presented in 2016 in a bronto report [3] that $64 \%$ of americans use their mobile phones to shop. The purchasing of print shop products and services are the second most likely online shopping purchased product or service captured from a combination of surveys outlined above that have attracted smartphone users.

Revised Manuscript Received on June 22, 2019.

Azham Hussain, School of Computing, Universiti Utara Malaysia, 06010 Sintok, Kedah, Malaysia

Emmanuel O.C. Mkpojiogu, School of Computing, Universiti Utara Malaysia, 06010 Sintok, Kedah, Malaysia

Khairi Suleiman, Pejabat Setiausaha Kerajaan Negeri Pulau Pinang, Komtar, Pulau Pinang, Malaysia.
These companies tremendous accomplishment implied that their use of mobile applications is user friendly. There are similar applications introduced in the market for the purchase and design of print shop products. Users are usually not attracted to the use any application that has low or poor usability.

Heuristic evaluation has been applied in the evaluation of mobile application because it is one of the best methods of the usability evaluation (UEMs) in use [4]. It is also the most favorite method in Human-Computer Interaction (HCI) [5]. However, no usability techniques have been used to evaluate any mobile print shop booking and design application even though usability evaluation techniques have been applied in many other areas of mobile applications and systems. The issues found in the mobile print shop booking and design applications are to be evaluated and identified. This research also intends to proffer recommendations and solutions for the improvement of the effectiveness, efficiency and user satisfaction of these related applications [6]. This present study aims at evaluating the usability of Achik.biz, a mobile print shop booking and design application with usability experts. A study conducted by [7] showed that the methods of usability inspection needed to be combined with the methods of the usability test such as heuristic evaluation. The application of the heuristic evaluation is to find the issues on the application based on the evaluation of experts. The application would be tested by the expert to find errors based on some heuristic principles and categorize these errors on the basis of the heuristic principles. The issues found on the heuristic evaluation can then be used in the development of test scenarios for usability testing. Moreover, after the issues are found by the usability experts, then real users can used for usability testing. Developing test scenarios for a whole application is time-consuming and unnecessary for applications that have so many pages or screens. Furthermore, the usage of the heuristics method and usability testing provide a platform the issues found by the experts to be verified by actual users.

For HCI experts the design of the user interface of an application is the main focus. They drive at producing good design and interface that fulfills users' requirement. According to [8], in developing e-commerce websites, usability and design features, such as layout, navigation, design, content, and performance should be considered. In addition, [9] applied the inquiry method in the conduct of online shopping website usability. The authors used a unstructured interviews with 20 interviewers and questionnaires. 
Unfortunately, the design prototype was not tested with real users. Usability can be defined as the extent to which a system or product is used by specified user in order to achieve effectiveness, efficiency and user satisfaction [6][10-16]. The completeness with which users complete their tasks with accuracy defines the effectiveness of the application. Also, the resources (e.g., time and mental efforts) expended by users to completely achieve their goals without errors defines efficiency. In addition, the positive attitude of users towards the use or after the use of a system defines the application's satisfaction. As users interact with the interface and as the evaluation is carried out, the task completion rate, the time taken to complete the task, and errors made, as well as the user's attitude [17] are captured. One of the inspection techniques is heuristic evaluation, conducted by usability experts or evaluators. The method drives at finding some issues on the application following a set of usability guidelines [7]. To decrease cost and produce results in short time, this usability evaluation method where there is no recruitment of users and which does not consume time [9] is employed. Based on [18], however, the results from heuristic evaluation cannot be completely trusted since actual users are not involved. The reasons for the conduct of heuristic evaluation are as follows [19]:

- To identify possible issues in an interface in the early stage of its development before the conduct of usability testing.

- As there are many pages or screens to be evaluated during usability test, the conduct of heuristics evaluation determines the possible issues to be found in usability test later.

Based on the literature study, no work was done on the heuristic evaluation of mobile print shop and design shopping application. This study would therefore conduct a heuristics evaluation to find issues based on expert views. A study conducted by [20] showed that the method of usability inspection can be combined with the method of usability testing [7]. The application of heuristic evaluation is to find issues on the application based on the evaluation of experts. The usability experts will heuristics guidelines to both fine and categorize errors. The issues found in the heuristic evaluation can later be used to develop test scenarios for usability testing. Moreover, after the experts have found the issues in the interface, then real users can be used to valid and verify the outcome.

\section{METHODOLOGY}

The following research protocol was used for this study: 1) literature review related to the usability evaluation methods (uems); 2) heuristic evaluation implementation; 3) observation and recommendations; 4) discussion and conclusion of the study. Firstly, this research was conducted by reviewing articles that are related to usability evaluation methods (uems). The aim of the review phase was to explore all methods available in prior studies on usability evaluation. Heuristic evaluation followed in the second phase. Three (3) usability experts conducted the usability evaluation of the mobile application following the principles of heuristic evaluation of touch screen-based mobile devices [21]. All the issues found were collated and analyzed by the experts [22]. The third phase involves the observation and recommendations by the experts. Lastly, the fourth phase discussed all the findings found during this research. Meanwhile, the evaluators were chosen in the heuristic evaluation, from the people who have worked as usability engineers or have knowledge on the area of the study. In order to find the issues in the application, the minimum number of evaluators (experts) allowed is two.

\section{RESULTS}

The results of the usability testing on mobile Achik.biz application will be presented in this section. Usability experts conducted the heuristic evaluation to find the application's usability issues using the principles of heuristic evaluation. In order, to find the application issues, each of the usability experts, individually evaluated the application using heuristic evaluation principles. All the issues that were found by each of the usability experts were combined in producing the report of the heuristic evaluation. The following table briefly reviews the most significant usability issues found by the 3 usability experts and the recommendation for addressing them.

Table. 1 Heuristic Evaluation Result

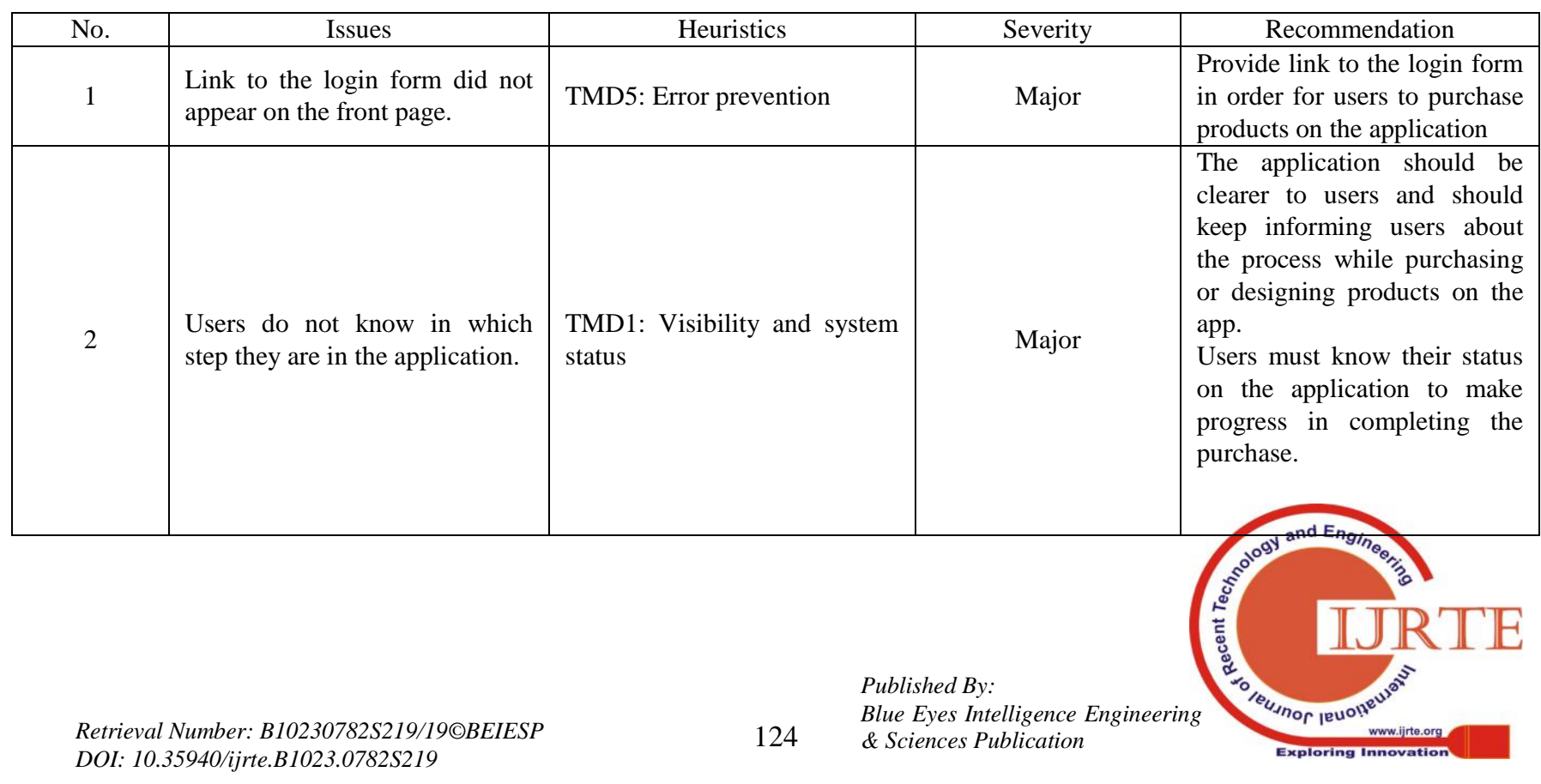




\begin{tabular}{|c|c|c|c|c|}
\hline 3 & $\begin{array}{l}\text { By providing two search icons, } \\
\text { users were confused as to which } \\
\text { one to select and which is the } \\
\text { main search icon. Search cannot } \\
\text { find any lists of the product. }\end{array}$ & $\begin{array}{l}\text { TMD8: Efficiency of use and } \\
\text { performance }\end{array}$ & Major & $\begin{array}{l}\text { All the product search } \\
\text { function should be able to } \\
\text { load and display the same } \\
\text { result. }\end{array}$ \\
\hline 4 & $\begin{array}{l}\text { Cannot exit from the } \\
\text { application. } \\
\text { User needs to press "home } \\
\text { button" on the device to exit the } \\
\text { application }\end{array}$ & $\begin{array}{l}\text { TMD3: User control and } \\
\text { freedom }\end{array}$ & Major & $\begin{array}{l}\text { The system should provide } \\
\text { exit link or button to exit from } \\
\text { the application. }\end{array}$ \\
\hline 5 & $\begin{array}{l}\text { Payment methods do not } \\
\text { function. }\end{array}$ & $\begin{array}{l}\text { TMD8: Efficiency of use and } \\
\text { performance }\end{array}$ & Major & $\begin{array}{l}\text { The payment method listed, } \\
\text { such as debit or credit should } \\
\text { be functioning well. } \\
\text { Provide payment to users } \\
\text { using the method available } \\
\text { such as debit or credit. }\end{array}$ \\
\hline 6 & $\begin{array}{l}\text { Designing interface on the } \\
\text { printing product is not user } \\
\text { friendly. }\end{array}$ & $\begin{array}{l}\text { TMD3: User control and } \\
\text { freedom }\end{array}$ & Major & $\begin{array}{l}\text { Hard for user to design their } \\
\text { own product because the } \\
\text { interface is not friendly. Some } \\
\text { buttons or icons do not } \\
\text { function well. } \\
\text { It is recommended that good } \\
\text { interface be provided so that } \\
\text { user can easily do their design } \\
\text { via their own creativity. } \\
\text { Ensure all icons are working } \\
\text { properly especially the text } \\
\text { icon. }\end{array}$ \\
\hline 7 & $\begin{array}{l}\text { Only providing one language on } \\
\text { the application }\end{array}$ & $\begin{array}{l}\text { TMD4: Consistency and } \\
\text { standards }\end{array}$ & Major & $\begin{array}{l}\text { The application should } \\
\text { provide other languages to } \\
\text { cater for users in their } \\
\text { location instead of only } \\
\text { English to prevent user } \\
\text { misunderstanding and to } \\
\text { enhance communication. }\end{array}$ \\
\hline 8 & $\begin{array}{l}\text { Link on the other products are } \\
\text { not active. }\end{array}$ & $\begin{array}{l}\text { TMD4: Consistency and } \\
\text { standards }\end{array}$ & Major & $\begin{array}{l}\text { The application should check } \\
\text { for the broken links on the } \\
\text { other products or not just hide } \\
\text { the link on the menu if not } \\
\text { applicable. }\end{array}$ \\
\hline 9 & $\begin{array}{l}\text { No back button or link when the } \\
\text { user receives message "no } \\
\text { products were found matching } \\
\text { your selection". }\end{array}$ & $\begin{array}{l}\text { TMD3: User control and } \\
\text { freedom }\end{array}$ & Minor & $\begin{array}{l}\text { The application should } \\
\text { provide the back button or } \\
\text { link to allow users to choose } \\
\text { another available product. }\end{array}$ \\
\hline 10 & $\begin{array}{l}\text { No error message or alert is } \\
\text { given to the user when } \\
\text { providing wrong number } \\
\text { coupon for discount. }\end{array}$ & $\begin{array}{l}\text { TMD10: Help for users } \\
\text { recognition and diagnosis }\end{array}$ & Minor & $\begin{array}{l}\text { Provide the appreciate } \\
\text { message to inform user when } \\
\text { there is wrong input. }\end{array}$ \\
\hline 11 & $\begin{array}{l}\text { Categories filter on product } \\
\text { function. Example: When a user } \\
\text { searches for an appointment } \\
\text { cards such as business card, the } \\
\text { application provides a postcard } \\
\text { flyer which does not meet } \\
\text { user's requirement from the } \\
\text { categories. }\end{array}$ & $\begin{array}{l}\text { TMD8: Efficiency of use and } \\
\text { performance }\end{array}$ & Minor & $\begin{array}{l}\text { Should filter the search result } \\
\text { accordingly }\end{array}$ \\
\hline 12 & $\begin{array}{l}\text { Delete / remove icon or button } \\
\text { in cart is too small. }\end{array}$ & $\begin{array}{l}\text { TMD12: Physical interaction } \\
\text { and ergonomics }\end{array}$ & Minor & $\begin{array}{l}\text { The application should } \\
\text { provide larger delete / remove } \\
\text { icon or button for all item in } \\
\text { the cart. }\end{array}$ \\
\hline
\end{tabular}




\section{CONCLUSION}

This study was conducted to evaluate the mobile usability of a mobile print shop and design shopping application. Heuristic evaluation methodology was employed. In the evaluation, three (3) usability experts were used and the results of their evaluation was quite revealing as a number of issues pertaining to the usability of the application were captured and suitable recommendations were proffered.

\section{REFERENCES}

1. A Look at the Evolving E-Commerce Landscape, RetrievedDecember02,2017,fromhttp://www.nielsen.com/my/en/insigh ts/news/2017/a-look-at-the-evolving-e-commerce-landscape.html (2017).

2. Canadian Mobile Wallet Users Set Mobile Payment Trends,RetrievedDecember02,2017,fromhttp://www.nielsen.com/ca/en/ insights/news/2017/canadian-mobile-wallet-users-set-mobile-paymenttrends.html (2017).

3. Younger consumers turn increasingly to mobile devices for buying as well as browsing. Retrieved December 02, 2017,fromhttps://www.digitalcommerce360.com/2016/04/25/youngerconsumers-turn-increasingly-mobile-devices-buying/ (2017).

4. J. Mankoff, A.K. Dey, G. Hsieh, J. Kientz, S. Lederer, and M. Ames, "Heuristic evaluation of ambient displays". In Proceedings of the SIGCHI Conference on Human factors in Computing Systems (ACM, 2003), pp. 169-176.

5. C. Forsell, and J. Johansson, "An heuristic set for evaluation in information visualization". In Proceedings of the International Conference on Advanced Visual Interfaces (ACM, 2010), pp. 199-206.

6. ISO 9241-11. Ergonomic requirements for office work with visual display terminals (vdts)-part 11: Guidance on usability. ISO Standard 9241-11: 1998. International Organization for Standardization (1998).

7. Holzinger, Usability engineering methods for software developers. Communications of the ACM, 48(1), 71-74 (2005).

8. R. Molich, and C. Wilson, "Tips and tricks for avoiding common problems in usability test facilitation". In CHI'08 extended abstracts on Human factors in computing systems (ACM, 2008), pp. 2379-2382).

9. F. Gündüz, and A.S.K. Pathan, On the key factors of usability in smallsized mobile touch-screen application. Int. J. Multimed. Ubiquitous Eng, 8(3), 115-138 (2013)

10. A. Hussain, E.O.C. Mkpojiogu, H. Almazini, and H. Almazini, "Assessing the usability of shazam mobile app". Proceedings of the 2nd International Conference on Applied Science and Technology (ICAST'17), Kedah, Malaysia, (AIP Conference Proceedings, 2017).

11. A. Hussain, E.O.C. Mkpojiogu, J. Musa, and S. Mortada, "A user experience evaluation of amazon kindle mobile application." Proceedings of the 2nd International Conference on Applied Science and Technology (ICAST'17), Kedah, Malaysia. (AIP Conference Proceedings, 2017).

12. A. Hussain, E.O.C. Mkpojiogu, N.M. Fadzil, and N.M. Hassan, N.M. "The UX of amila pregnancy on mobile device." Proceedings of the 2nd International Conference on Applied Science and Technology (ICAST'17), Kedah, Malaysia. (AIP Conference Proceedings, 2017).

13. Hussain, A., AbdRazak, M.N.F., Mkpojiogu, E.O.C. and Hamdi, M.M.F. (2017). UX evaluation of a video streaming application with teenage users. Journal of Telecommunication, Electronic \& Computer Engineering (JTEC), 9 (2-11), 129-131.

14. A. Hussain, M. Isam, and E.O.C. Mkpojiogu, A UX assessment of a mobile recommender app for household electrical energy savings. Journal of Telecommunication, Electronic \& Computer Engineering (JTEC), 9 (2-11) (2017).

15. Hussain, H.A. Razak, and E.O.C. Mkpojiogu, The perceived usability of automated testing tools for mobile applications. Journal of Engineering Science and Technology (JESTEC), 4, 89-97 (2017).

16. Hussain, E.O.C. Mkpojiogu, and N.M.D. Jasin, Usability metrics and methods for public transportation mobile applications: a systematic literature review. Journal of Engineering Science and Technology (JESTEC), 4, 98-105 (2017)

17. A, Dillon, Beyond usability: process, outcome and affect in humancomputer interactions. Canadian Journal of Library and Information Science (2002).

18. F. Gündüz, and A.S.K. Pathan, "Usability improvements for touchscreen mobile flight booking application: A case study". In 2012
International Conference on Advanced Computer Science Applications and Technologies (ACSAT) (IEEE, 2012), pp. 49-54.

19. H. Petrie, and N. Bevan, The evaluation of accessibility, usability, and user experience. In The universal access handbook (CRC Press, 2009) pp. $1-16$.

20. A. Kaikkonen, A Kekäläinen, M. Cankar, T. Kallio, and A. Kankainen, Usability testing of mobile applications: A comparison between laboratory and field testing. Journal of Usability Studies, 1(1), 4-16 (2005).

21. R. Inostroza, C. Rusu, S. Roncagliolo, and V. Rusu, "Usability heuristics for touchscreen-based mobile devices: update". In Proceedings of the 2013 Chilean Conference on Human-Computer Interaction (ACM, 2013), pp. 24-29.

22. J. Nielsen, First rule of usability? Don't listen to users. The Alertbox: Current Is-sues in Web Usability. See:< http://www. useit. com/alertbox/20010805. html (2001). 